\title{
Tannery Clusters in India and waste management practices in tannery intensive states - inventory and status
}

\author{
Shradha Gupta, Mita Sharma andU.N Singh \\ Central Pollution Board, East Arjun Nagar, Delhi-110032
}

\begin{abstract}
Clusterisation is undoubtedly the most economical, organized and self-sustaining driving mechanism for cleaner leather production. The Indian Tannery sector has particularly shown shifting trend from scattered units to clusters in recent decade with complete homogeneity i.e. industries involved only in tannery and allied activities. The paper gives insight into tannery clusters in India, with comparison of cluster characteristics and waste management practices in tannery intensive states.

Study identifies 113 Tannery Clusters in India, tannery intensive states being Tamil Nadu (15 Clusters), Uttar Pradesh (13 Clusters), West Bengal (7 Clusters) and Punjab (15 clusters). Other States with prominence of tannery activities are Haryana(9 clusters), Maharashtra (13 clusters), Bihar (12 clusters), Andhra Pradesh,(7 clusters), Rajasthan (11 clusters), with fewer units in Gujarat (2 clusters), Karnataka (1 cluster at Bangalore), Odisha (4 Clusters), Delhi (2 clusters), Himachal Pradesh (1 cluster), Uttarakhand (1 cluster)and Goa (scattered units). Micro scale units are not considered in this study as the study pertains to small and medium enterprises.

Jalandhar (Punjab) cluster has highest number of Medium scale units and second highest number of large scale units (10) after Tamil Nadu (13), inspite of the huge difference in total number of units in the clusters (110 in Jalandhar as against 704 in Tamil Nadu). Unit wise Tamil Nadu (704) has the highest number of units involved in tannery activities, followed by, West Bengal. Calcutta Leather Complex (462), Uttar Pradesh, Jajmau (405), and Punjab, Jalandhar (110).

Tannery is the only sector with highest number of dedicated CETPs showing a strong initiative for greener indentation. Study reveals that $\mathbf{4 2} \mathbf{\%}$ of the total number of tannery clusters in four tannery intensive states is connected to CETP. Tamil Nadu has $93.3 \%$ of units connected to CETP, followed by Uttar Pradesh (30.8\%), West Bengal (14.3\%) and Punjab (13.3\%).

Key Words: Clusters, cleaner practices, greener production, wet blue, EI tanning.
\end{abstract}

\section{Introduction}

One of the unique features of Leather Industry Sector in India is its inherent characteristic to occur in clusters right from primitive time. Tanneries have always occurred in groups particularly the slaughter houses. As per CLRI report January 2013, about 42,000 units are registered under SSI. About 75 percent of tanneries in India are small-scale units. Another 20 percent are medium sized and only 5 percent are large-scale units. Total production of leather is from small and micro sector accounting for about $60 \%-65 \%$ of the total leather production in the country.The states of Tamil Nadu, West Bengal and Uttar Pradesh together account for $88 \%$ of the tannery units of the country.In recent decade Punjab has emerged as a major wet blue leather producer.

India has $10 \%$ of the world's raw material base[3]. Raw material is of fine quality with versatile biopolymer collagen. More than sufficient productive capacity in tanning exists in India as India has the largest livestock holding country in the world with 21 percent of the world's large animals (buffalo \& cow) and 11 percent of the world's small animals (goat \& sheep).Leather in India is generally produced from hides or skins of milch animals such as cow or buffalo (called hides) and goat or sheep (called skins). Leather from other sources are almost rare such as snake, rhinos, cheetah, etc. in India. Study shows that state wise, Himachal Pradesh and Punjab produces the maximum number of cattle skin. West Bengal Produces maximum number of buffalo hides, Kerala and Chennai produces sheep skins, while Uttar Pradesh produces goat skins. Leather industry in Uttar Pradesh is predominantly buffalo leather based, while that in West Bengal it is predominantly cow leather based and in Punjab it is predominantly cow and buffalo leather based. In Tamil Nadu, the tanneries in Vaniyambadi, Ambur, Tricy, Dindigul processes mostly goat and sheep skins, while the tanneries in Ranipet, Pernambut, Edrode and Pallavaram processes hides. Bihar leather industry is mainly goat leather based.

The Indian leather industry employs about 2.5 million workforceof which $30 \%$ is women.

Segmentation within the Sector

Based on various attributes of the sector like processing capacity, raw materials, production capacity, tanning process, annual turnover and final products, the sector can be segmented as below: 
Table 1 : Segmentation within the Tannery Sector

\begin{tabular}{|c|c|c|}
\hline $\begin{array}{l}\text { Based on Processing Capacity of Wet } \\
\quad \text { Salted hide / skins (kg/day) } \\
\text { 1. Large units : > 5000 } \\
\text { 2. Medium : } 2000-5000 \\
\text { 3. Small : <2000 }\end{array}$ & $\begin{array}{l}\text { Based On Tanning Process } \\
\text { Vegetable(EI) Tanning } \\
\text { Chrome Tanning } \\
\text { Other mineral tanning }\end{array}$ & $\begin{array}{l}\text { Based on Raw Material } \\
\text { Hide : Bovine: cows , } \\
\text { buffaloes } \\
\text { Skin : Goats, sheep (flayed } \\
\text { material called 'skin') }\end{array}$ \\
\hline $\begin{array}{l}\text { Based on Product Manufactured } \\
\text { 1. Tanning and finishing } \\
\text { 2. Footwear \& footwear components } \\
\text { 3. Leather garments } \\
\text { 4. Leather goods } \\
\text { 5. Accessories (bags, wallets, belts, } \\
\text { gloves) } \\
\text { 6. Saddlery\& harness articles }\end{array}$ & $\begin{array}{l}\text { Based on processing activities } \\
\text { 1. Raw Hide to Leather Product Processing Units. } \\
\text { 2. Raw Hide to Finished Leather Processing Units. } \\
\text { 3. Raw Hide to Wet Blue Processing Units. } \\
\text { 4. Wet Blue to Finished Leather Processing Units. } \\
\text { 5. Wet Blue to Leather Product Processing Units. } \\
\text { 6. Raw to E.I Tanned Leather Units. } \\
\text { 7. Dry (Finished leather to Leather Products) Processing } \\
\text { Units. } \\
\text { 8. Secondary Leather waste (eg. Shavings, fleshings, hairs } \\
\text { etc.) processing Units which produces glue, leather } \\
\text { boards, meat meal, etc. }\end{array}$ & $\begin{array}{l}\text { Based on Annual Turnover } \\
\text { 1. Small Scale Units : } \\
\text { < Euro 2.25 Million } \\
\text { 2. Medium Scale Units: Euro } \\
\text { 2.25 - Euro 11.25 Million } \\
\text { 3. Large Scale Units : Euro } \\
\text { 11.25 - Euro 41.25 Million }\end{array}$ \\
\hline
\end{tabular}

India has large institutional set up (more than 15 dedicated institutional set ups) that support the leather industry in specific areas such as product development, design and R \& D. These institutions enable capability building in the industry and help it become globally competitive.

The report is based on the field visit to clusters in Uttar Pradesh, Punjab, West Bengal and report submitted by CLRI to CPCB on Tamil Nadu Cluster.

\section{Inventory of Leather Processing Clusters inIndia}

Tanneries have always occurred in groups often closer to slaughter housesin 'clusters', since 'Clustering' offers the benefits of easy availability of raw materials, manpower, technical knowhow, laboratory testing facilities, access to Common Treatment Facilities ex. CETP, CCRUs and is a self sustainable and self driving mechanism. Table 2. : State-wise distribution of Tannery Clusters in India

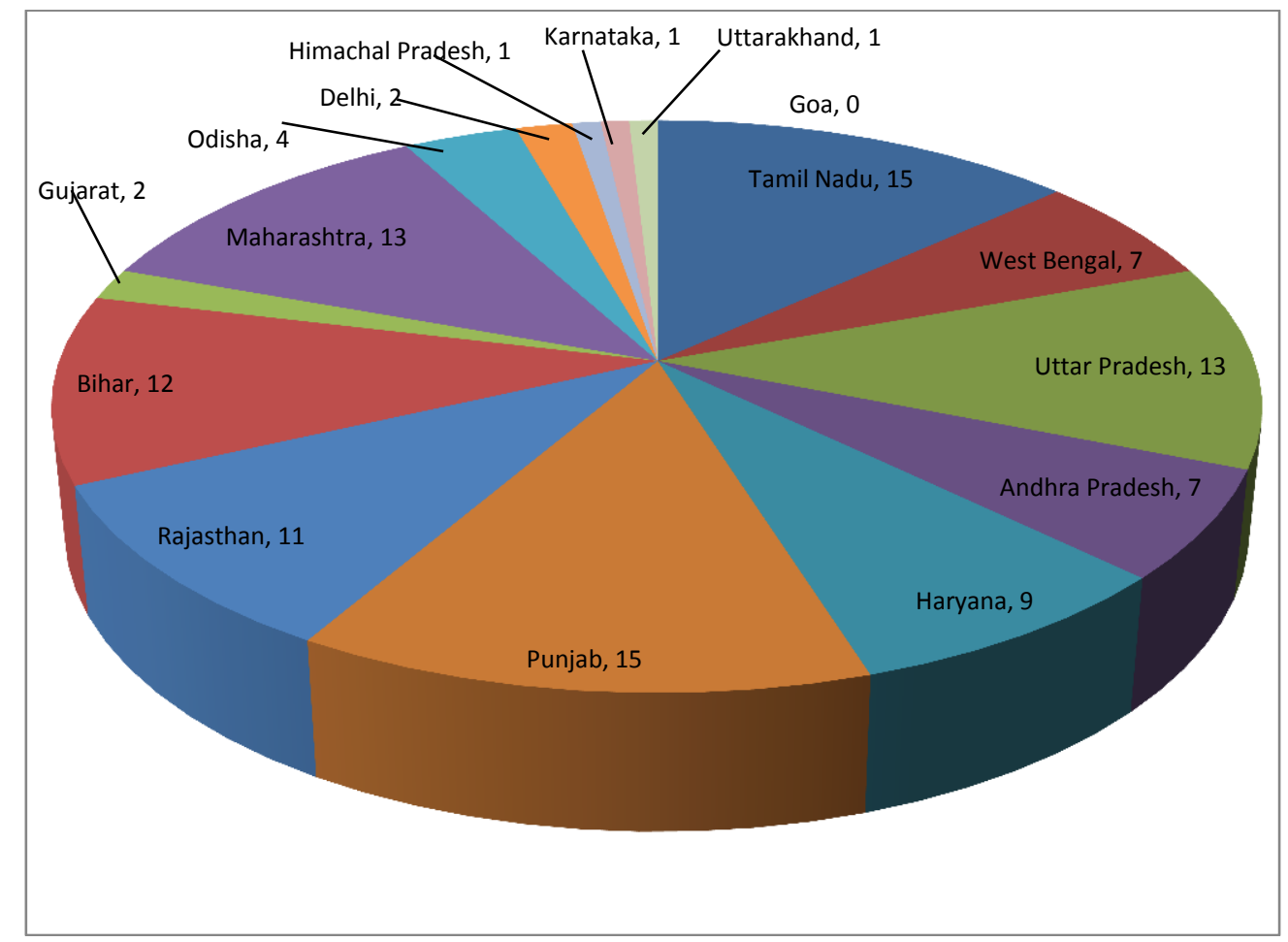



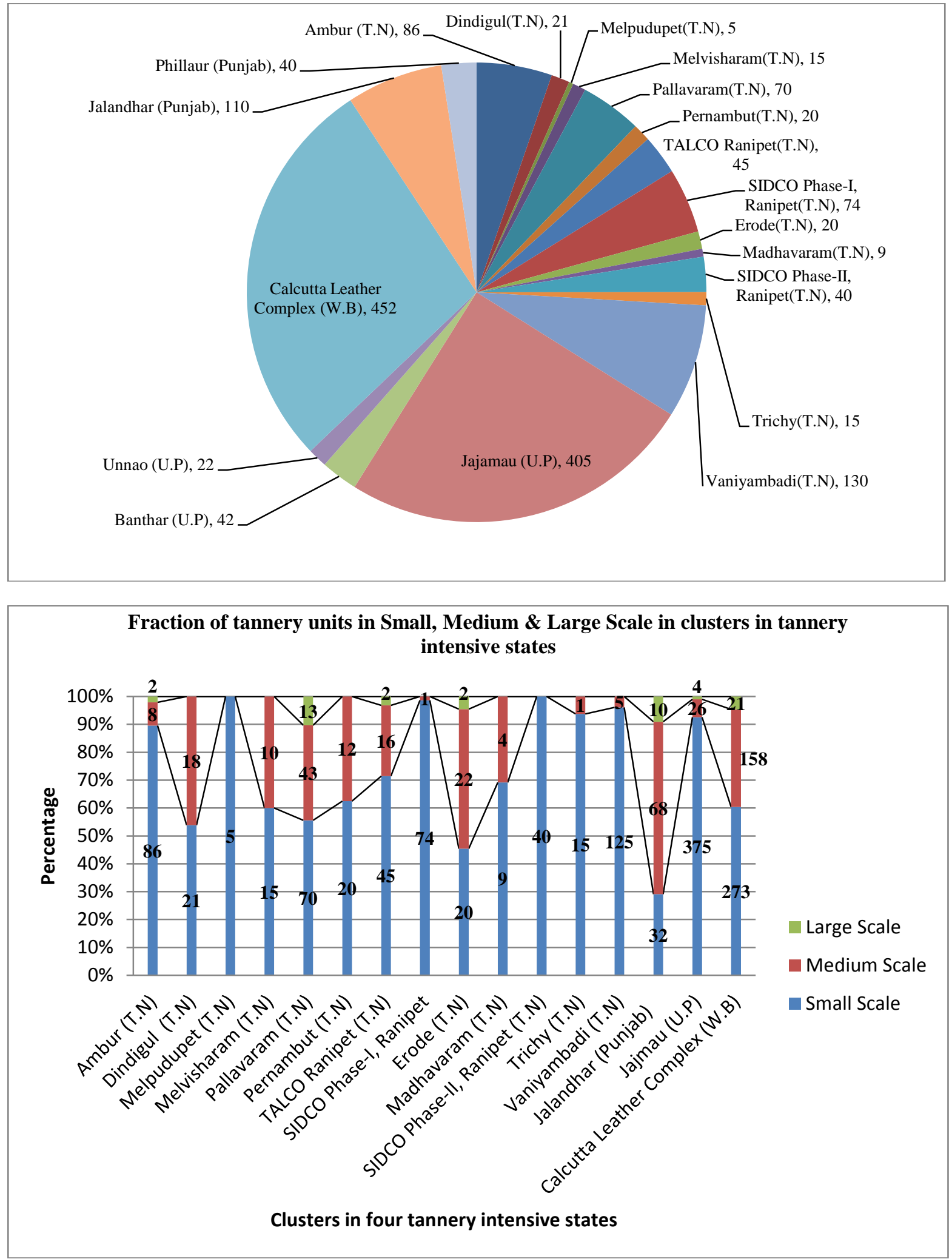

N.B: except for Tamil Nadu, other states are represented by single cluster.

A prominent observation is that Jalandhar (Punjab) cluster has highest number of Medium scale units and second highest number of large scale units (10) after Tamil Nadu (13), inspite of the huge difference in total number of units in the clusters (110 in Jalandhar as against 704 in Tamil Nadu). 
Tannery Clusters in India and waste management practices in tannery intensive states - inventory...

Table: Satate-wise Comparison of processing hierarchy adopted in different clusters in tannery intensive states

\begin{tabular}{|c|c|c|}
\hline \multicolumn{2}{|r|}{ Cluster Name } & Process dominance in the clusters (number of units) \\
\hline \multicolumn{3}{|r|}{ TAMIL NADU } \\
\hline 1 & Ambur & $\begin{array}{ll}\text { a) } & \text { Raw to Finished }-66 \\
\text { b) } & \text { Semi-finished to Finished }-30\end{array}$ \\
\hline 2 & Dindigul & $\begin{array}{ll}\text { a) } & \text { Raw to E.I }- \text { 22 } \\
\text { b) } & \text { Raw to Wet Blue/ Raw E.I - } 15 \\
\text { c) } & \text { Raw to Finished- } 1 \\
\text { d) } & \text { Raw to Wet Blue- } 1 \\
\end{array}$ \\
\hline 3 & Melpudupet & $\begin{array}{l}\text { a) } \quad \begin{array}{l}\text { Raw to Finished }-1 \\
\text { (no info. about rest } 4 \text { units) }\end{array} \\
\end{array}$ \\
\hline 4 & Melvisharam & $\begin{array}{ll}\text { a) } & \text { Raw to Semi-Finished }-1 \\
\text { b) } & \text { Raw to Finished }-1 \\
\text { (no info. about rest } 23 \text { units) }\end{array}$ \\
\hline 5 & Pallavaram & $\begin{array}{ll}\text { a) } & \text { Raw to Wet Blue or Wet blue to Finished }-03 \\
\text { b) } & \text { Wet Blue to Finished \& E.I to Finished - 24 } \\
\text { c) } & \text { Wet Blue to Finished- 85 } \\
\text { d) } & \text { Raw to Pickle- 01 } \\
\text { e) } & \text { Pickle to Chamos- 01 } \\
\text { f) } & \text { Crust to Finished Leather- 02 } \\
\text { g) } & \text { E.I to Finished Leather - } 10 \\
\end{array}$ \\
\hline 6 & Pernambut & $\begin{array}{l}\text { Raw to Finished - } 03 \\
\text { Raw to Wet Blue - } 02 \\
\text { Raw to EI - } 24 \\
\text { Raw to Wet Blue or EI }-03 \\
\end{array}$ \\
\hline 7 & TALCO Ranipet & $\begin{array}{l}\text { Raw to Semi finished or Finished- } 37 \\
\text { Semi-Finished to Finished- } 22 \\
\text { Raw to Semi finished- } 03 \\
\text { Raw to Finished- } 01 \\
\end{array}$ \\
\hline 8 & SIDCO Phase-I, Ranipet & Semi-Finished to Finished Leather- 75 \\
\hline 9 & Erode & $\begin{array}{l}\text { Raw to Finished Leather- } 12 \\
\text { Raw to Wet Blue }-22 \\
\text { Wet Blue to Finished Leather- } 02 \\
\text { Raw to E.I }-07 \\
\text { Raw to Wet Blue or E.I }-01\end{array}$ \\
\hline 10 & Madhavaram & $\begin{array}{ll}\text { a) } & \text { E.I to Finished Leather - 08 } \\
\text { b) } & \text { Wet Blue or E.I to Finished - } 05\end{array}$ \\
\hline 11 & SIDCO Phase-II, Ranipet & Semi-finished to Finished Leather - 40 \\
\hline 12 & Trichy & $\begin{array}{l}\text { Raw to E.I }-14 \\
\text { Raw to W.B }-01 \\
\text { Raw to W.B or E.I - } 01\end{array}$ \\
\hline 13 & Vaniyambadi & Raw to Finished - 130 \\
\hline & & UTTAR PRADESH \\
\hline 1 & Jajmau & $\begin{array}{ll}\text { a) } & \text { Raw to Finished }-41 \\
\text { b) } & \text { Raw to W.B }-290 \\
\text { c) } & \text { Wet Blue to Finished Leather }-11 \\
\text { d) } & \text { Raw to E.I }-20 \\
\end{array}$ \\
\hline & & WEST BENGAL \\
\hline 1 & Calcutta Leather Complex & $\begin{array}{ll}\text { b) } & \text { Raw to Finished- } 199 \\
\text { c) } & \text { Raw to Wet Blue - } 182 \\
\text { d) } & \text { Wet Blue to Finished - } 14 \\
\text { e) } & \text { Raw to E.I }-08 \\
& \text { (no info. about rest } 49 \text { units) }\end{array}$ \\
\hline & & PUNJAB \\
\hline 1 & Jalandhar & $\begin{array}{ll}\text { a) } & \text { Raw Hide to Wet Blue-23. } \\
\text { b) } & \text { Raw Hide to Finished Leather }-20 \\
\text { c) } & \text { Raw Hide to Leather Product- } 09 \\
\text { d) } & \text { Wet Blue to Finished Leather-10 } \\
\text { e) } & \text { Wet Blue to Leather Product -06 }\end{array}$ \\
\hline 2 & Phillaur & $\begin{array}{ll}\text { a) } & \text { Vegetable bag tanning units }-38 \\
\text { b) } & \text { Chrome tanning units }-1 \\
\text { c) } & \text { One unit does vegetable tanning followed by fat liquoring }\end{array}$ \\
\hline
\end{tabular}

Out of total of 1671 units identified in Tannery intensive states of Tamil Nadu, Uttar Pradesh, West Bengal and Punjab (Except for Tamil Nadu all other three states are represented bya single cluster), only 1510 units can be characterize based on the process dominance in the units based on the field data. Following graph represents the major tanning operations in different cluster units. 


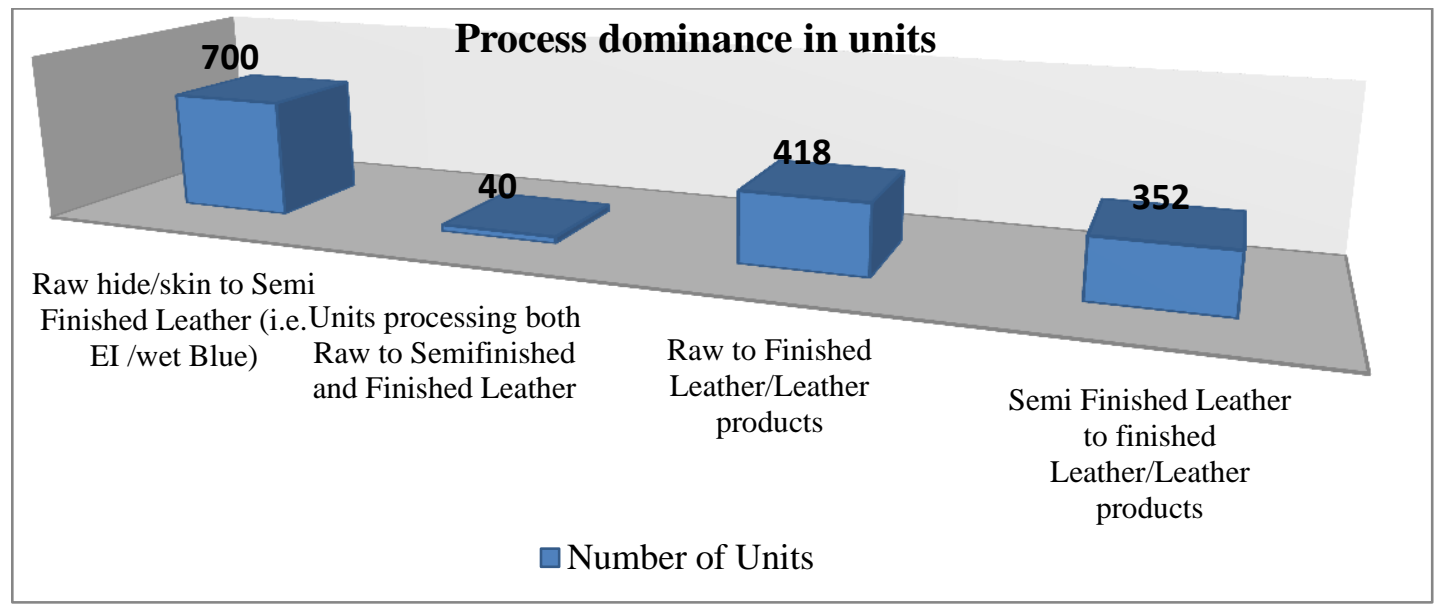

Production of Semi-finished leather (wet blue or E.I) from raw hide/skin is the predominant process in SME units, however, production of finished leather from wet blue is the major leather product in the country, which indicates that mostly large units are involved in production of Finished leather or leather products. Finished leather production is highest in Tamilnadu followed by West Bengal. Raw to Wet Blue Leather production is highest in Uttar Pradesh (Jajamau) as against Tamil Nadu which has highest leather production. After Jajamau cluster (UP) West Bengal leads in Wet Blue Leather production followed by Punjab (Jalandhar cluster) leaving Tamil Nadu at the lowest wet blue leather producing state. Tamil Nadu has highest EI tanned leather production with lowest number of percentage units involved in EI Tanning with most of them being in medium units, followed by Uttar Pradesh with highest percentage of EI units most of them being in micro, small and medium scale.In Punjab no EI tanning is practiced in Jalandhar cluster.

Drum Tanning (a cleaner practice) is predominant process in Tamil Nadu, whereas other sates show prominence of both pit \& drum tanning operations. In Punjab there is clear demarcation of Drum tanning in Jalandhar cluster and pit tanning in Phillaur cluster.

Table: Satate-wise Comparison of clusters in tannery intensive states w.r.s.t raw material, process and product

\begin{tabular}{|c|c|c|c|c|c|c|c|c|c|c|}
\hline \multirow{2}{*}{$\begin{array}{l}\text { Clusters } \\
\quad \text { in } \\
\text { Tannery } \\
\text { Intensive } \\
\text { States }\end{array}$} & \multicolumn{2}{|c|}{ Tanning Practice } & \multicolumn{2}{|c|}{ Tanning Method } & \multicolumn{2}{|c|}{ Raw Material } & \multicolumn{3}{|c|}{ Major Tannery Product } & \multirow[b]{2}{*}{$\begin{array}{c}\text { Speciality } \\
\text { Tannery } \\
\text { Product }\end{array}$} \\
\hline & $\begin{array}{c}\text { Vegetable/E } \\
\text {.I tanning }\end{array}$ & $\begin{array}{l}\text { Chrome } \\
\text { tanning }\end{array}$ & $\begin{array}{c}\text { Drum } \\
\text { Tanning }\end{array}$ & $\begin{array}{c}\text { Pit } \\
\text { Tannin } \\
g\end{array}$ & Hide & Skin & $\begin{array}{l}\text { Wet } \\
\text { Blue }\end{array}$ & $\begin{array}{c}\text { Finishe } \\
d \\
\text { Leathe } \\
r\end{array}$ & $\begin{array}{c}\text { Leathe } \\
r \\
\text { Produc } \\
\text { ts }\end{array}$ & \\
\hline Tamil Nadu & $\begin{array}{c}\sqrt{ } \\
\text { (accounting for } \\
30 \% \text { of the total } \\
\text { tanned leather) }\end{array}$ & $\begin{array}{c}\sqrt{ } \\
\text { predominan } \\
\mathrm{t})\end{array}$ & $\sqrt{ }$ & $\mathrm{X}$ & $\begin{array}{c}\sqrt{ } \\
\text { used mainly } \\
\text { in Ranipet, } \\
\text { Pernambut, } \\
\text { Erode and } \\
\text { Pallavaram) }\end{array}$ & $\begin{array}{c}\sqrt{ } \\
\text { (used mainly } \\
\text { in } \\
\text { Vaniyambadi, } \\
\text { Ambur, } \\
\text { Trichy\& } \\
\text { Dindigul) }\end{array}$ & \begin{tabular}{|c|} 
\\
Erode is the \\
India's \\
Largest \\
center for \\
'wet blue' \\
leather \\
production)
\end{tabular} & $\sqrt{ }$ & $\sqrt{ }$ & - \\
\hline Uttar Pradesh & \begin{tabular}{|c|}
$\sqrt{ }$ \\
(vegetable sole \\
leather is \\
produced in \\
Kanpur) \\
\end{tabular} & $\begin{array}{c}\sqrt{ } \\
\text { predominan } \\
\mathrm{t})\end{array}$ & $\sqrt{ }$ & $\sqrt{ }$ & \begin{tabular}{|c|} 
\\
predominan \\
tly buffalo \\
leather \\
based) \\
\end{tabular} & $\begin{array}{c}\sqrt{ } \\
\text { (very few } \\
\text { units) }\end{array}$ & $\sqrt{ }$ & \multicolumn{2}{|c|}{$\begin{array}{l}\qquad \sqrt{ } \\
\text { (largest producer of } \\
\text { finished leather and } \\
\text { leather products) }\end{array}$} & $\begin{array}{c}\text { Harness and } \\
\text { Saddlery items, } \\
\text { Heavy leather }\end{array}$ \\
\hline West Bengal & $\sqrt{ }$ & $\begin{array}{c}\sqrt{ } \\
\text { predominan } \\
\mathrm{t})\end{array}$ & $\sqrt{ }$ & $\sqrt{ }$ & $\begin{array}{c}\sqrt{ } \\
\text { predominan } \\
\text { tly cow } \\
\text { leather } \\
\text { based) }\end{array}$ & 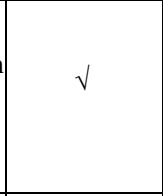 & $\sqrt{ }$ & \multicolumn{2}{|c|}{$\begin{array}{l}\sqrt{ } \\
\text { (largest producer of } \\
\text { finished leather and } \\
\text { leather products) }\end{array}$} & $\begin{array}{l}\text { Shantiniketani } \\
\text { leather products } \\
\text { are specialty } \\
\text { leather goods } \\
\text { made out of E.I } \\
\text { Tanned Leather }\end{array}$ \\
\hline Punjab & $\begin{array}{c}\sqrt{ } \\
\text { (practiced in } \\
\text { Phillaur cluster) }\end{array}$ & \begin{tabular}{|}
$\qquad$ \\
practiced in \\
Jalandhar \\
cluster)
\end{tabular} & $\begin{array}{l}\sqrt{ } \\
\text { (practiced in } \\
\text { Jalandhar } \\
\text { cluster) }\end{array}$ & \begin{tabular}{|c}
$\quad \sqrt{ }$ \\
(practiced \\
in Phillaur \\
cluster)
\end{tabular} & $\begin{array}{c}\sqrt{ } \\
\text { (both cow } \\
\text { and buffalo } \\
\text { leather } \\
\text { based) }\end{array}$ & $\begin{array}{c}\sqrt{ } \\
\text { (very few } \\
\text { units) }\end{array}$ & $\begin{array}{c}\sqrt{ } \\
\text { Jalandhar is } \\
\text { the largest } \\
\text { producer of } \\
\text { wet blue } \\
\text { after Erode) }\end{array}$ & $\sqrt{ }$ & $\sqrt{ }$ & $\begin{array}{c}\text { Jootisand } \\
\text { Mozdis in } \\
\text { vegetable } \\
\text { tanned leather } \\
\text { with colorful } \\
\text { threads. }\end{array}$ \\
\hline
\end{tabular}

\section{Waste management Practices:}

\section{Waste water: Pre-treatment \& CETPs}

The concept of Common Effluent Treatment Plant (CETP) was developed to achieve end-of-pipe (EoP) treatment of combined wastewater at lower unit cost than could be achieved by individual industries and to 
Tannery Clusters in India and waste management practices in tannery intensive states - inventory...

facilitate discharge, monitoring and enforcement by regulatory agencies to ensure regular satisfactory operation. The scheme promotes establishment of common facilities for treatment of effluents generated from SSI units located in clusters through financial assistance in the form of 50\% subsidy on capital ( $25 \%$ central subsidy plus matching $25 \%$ state subsidy).

The graph below is based on CPCB's updated data on CETPs connected to tannery clusters.

Fig.: Percentage of Tannery Clusters Connected to CETP in tannery intensive states

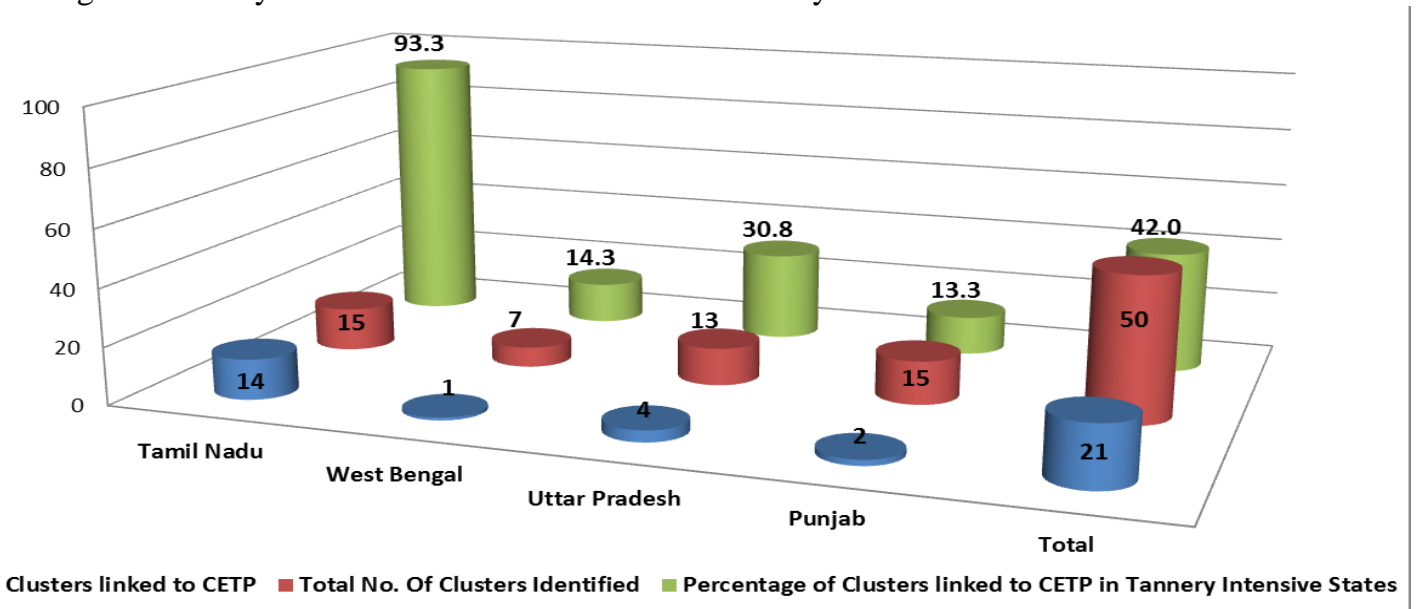

No. of Clusters linked to CETP $\quad$ Total No. Of Clusters Identified $\quad$ Percentage of Clusters linked to CETP in Tannery Intensive States

Karnataka has one CETP at Lidkar, Bangalore and Rajasthan has one at Jaipur. No information is available for other clusters.

Total 23 tannery dedicated CETPs have been identified in the present study of which 16 has been characterized but is beyond the preview of the present paper.

Table: Status of Tannery clusters in Tamil Nadu connected to CETP/ETP

\begin{tabular}{|c|c|c|c|c|}
\hline Sl. & Tannery Clusters & No. of Units & ETP Status & CETP Status \\
\hline 1 & Ranipet & $\begin{array}{c}63 \\
\text { + Micro scale units } \\
\text { engaged in chemical, } \\
\text { leather and tool making }\end{array}$ & $\begin{array}{l}4 \text { units have individual } \\
\text { ETPs. }\end{array}$ & 59 units are connected to CETP \\
\hline 2 & Ambur & ( & $\begin{array}{l}12 \text { units have individual } \\
\text { ETPs }\end{array}$ & $\begin{array}{l}\text { 1. } 56 \text { units are connected to Thutipet } \\
\text { CETP } \\
\text { 2. } 28 \text { units are connected to Malligaithope } \\
\text { CETP. }\end{array}$ \\
\hline 3 & Vaniyambadi & 130 & $\begin{array}{l}10 \text { units have individual } \\
\text { ETPs. }\end{array}$ & $\begin{array}{l}\text { 1. } 110 \text { units connected to Valayampet CETP } \\
\text { 2. } 10 \text { units connected to Udayendiram CETP. }\end{array}$ \\
\hline 4 & Dindigul & 39 & & All units are connected to CETP \\
\hline 5 & Erode & 44 & $\begin{array}{l}\text { All the units have } \\
\text { individual ETPs }\end{array}$ & 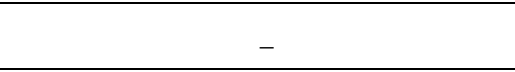 \\
\hline 6 & Trichy & 16 & $\begin{array}{l}\text { All the units have } \\
\text { individual ETPs }\end{array}$ & - \\
\hline 7 & $\begin{array}{l}\text { SIDCO } \\
\text { Phase II }\end{array}$ & 40 & 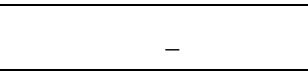 & \multirow{4}{*}{ All units connected to CETP } \\
\hline 8 & SIDCO, Phase I & 87 & - & \\
\hline 9 & Pernambut & 32 & & \\
\hline 10 & Pallavaram & 126 & & \\
\hline 11 & Melvisharam & 25 & 1 unit has individual ETP & 24 units connected to CETP \\
\hline 12 & Melpudupet & 5 & & \multirow{2}{*}{ All units connected to CETP } \\
\hline 13 & Madhavaram & 13 & & \\
\hline 14 & Kelambakkam & 09 & $\begin{array}{l}\text { All the units have } \\
\text { individual ETPs }\end{array}$ & - \\
\hline 15 & Chennai & 1199 & No information available & No information available \\
\hline
\end{tabular}

\section{Comparison of Pretreatment Methods:}

Before disposing effluent to CETP, member tannery units are required to pre-treat their effluent.

A comparison of the pre-treatment technologies followed in different Tannery clusters are given below in the table in the table below:

Table: State-wise pretreatment technologies adopted in different clusters

\begin{tabular}{|c|c|c|}
\hline Sl. & Cluster & Pre-treatment practices adopted \\
\hline \multicolumn{2}{|c|}{ TAMIL NADU } \\
\hline
\end{tabular}


Tannery Clusters in India and waste management practices in tannery intensive states - inventory...

\begin{tabular}{|c|c|c|}
\hline Sl. & Cluster & Pre-treatment practices adopted \\
\hline 1 & Ambur, Vaniyambadi & $\begin{array}{l}\text { Individual pre-treatment systems with screens, collection tank, pre-settler and sludge } \\
\text { dewatering systems. } \\
\text { Up-gradation : } \\
\text { a) Flow meter connected to centralized data collection system installation } \\
\text { b) TDS meter to measure TDS concentration before conveying effluent to } \\
\text { CETP. }\end{array}$ \\
\hline 2 & $\begin{array}{l}\text { Madhavaram, SIDCO Phase-I,SIDCO, } \\
\text { Phase-II }\end{array}$ & $\begin{array}{l}\text { Individual pre-treatment systems with mainly consisting of screens for grits removal } \\
\text { and Flow meters (TSS is very less in effluent as the units are licensed to process only } \\
\text { semi-finished to finished leather) }\end{array}$ \\
\hline \multirow[t]{2}{*}{3} & Ranipet & $\begin{array}{l}\text { Individual pre-treatment systems with screens, collection tank, pre-settler and sludge } \\
\text { dewatering systems. Flow meters are mandatory }\end{array}$ \\
\hline & $\begin{array}{l}\text { Dindigul, Melvisharam, Melpudupet, } \\
\text { Pallavaram, Pernambut, }\end{array}$ & $\begin{array}{l}\text { Individual pre-treatment systems with screens, collection tank, pre-settler and sludge } \\
\text { dewatering systems. }\end{array}$ \\
\hline \multicolumn{3}{|r|}{ UTTAR PRADESH } \\
\hline 5 & Banthar, Jajamau, Unnnao & $\begin{array}{l}\text { Individual pre-treatment systems with screens, collection tank, pre-settler and sludge } \\
\text { dewatering systems. }\end{array}$ \\
\hline \multicolumn{3}{|r|}{ WEST BENGAL } \\
\hline 6 & Kolkata & $\begin{array}{l}\text { Individual pre-treatment systems with screens, collection tank, pre-settler and sludge } \\
\text { dewatering systems. }\end{array}$ \\
\hline \multicolumn{3}{|r|}{ PUNJAB } \\
\hline 7 & Jalandhar & $\begin{array}{l}\text { Individual pre-treatment systems with screens, collection tank, pre-settler and sludge } \\
\text { dewatering systems. }\end{array}$ \\
\hline
\end{tabular}

Table: Summary of wastewater management intannery intensive states

\begin{tabular}{|l|c|l|}
\hline \multirow{4}{*}{$\begin{array}{l}\text { Effluent } \\
\text { Management }\end{array}$} & T.N & $\begin{array}{l}\text { Water scarcity enforces ZLD implementation; CETPs in Tamilnadu are most modernized CETPs with } \\
\text { MVR and R.O systems; All the units have Pre- treatment facility with flow meters. }\end{array}$ \\
\cline { 2 - 3 } & U.P. & Units have either individual ETPs or connected to CETPs. \\
\cline { 2 - 3 } & $\begin{array}{c}\text { West } \\
\text { Bengal }\end{array}$ & $\begin{array}{l}\text { Calcutta Leather Complex is world's largest Integrated Leather Complex;None of the units have } \\
\text { individual ETPs.; All the units are connected to CETP }\end{array}$ \\
\cline { 2 - 3 } & Punjab & $\begin{array}{l}\text { None of the units have individual ETP, all are connected to CETP for Jalandhar cluster however for } \\
\text { Phillaur no specific information is available as most of the units are of micro scale and are connected to } \\
\text { CETP. }\end{array}$ \\
\hline
\end{tabular}

\section{Comparison of CETP Treatment Charges}

Member units to CETPs are charged based on a range of parameters varying from state to state.

The table gives the basis of CETP charges in four tannery intensive states.

Table: Comparison of CETP charges in tannery intensive states

\begin{tabular}{|l|l|}
\hline Tannery Cluster & Basis for CETP charges for member tannery units \\
\hline \multicolumn{1}{|c|}{ TAMIL NADU } \\
\hline Ambur and Vaniyambadi & $\begin{array}{l}\text { Charges are based on the Volume of Effluent Discharged. } \\
\text { Up-gradation } \\
\text { Charges will be based on the TDS load of the effluent }\end{array}$ \\
\hline $\begin{array}{l}\text { Dindigul, Madhavaram, Melvisharam, Melpudupet, } \\
\text { Pallavaram, Pernambut and SIDCO,Phase-I\&II }\end{array}$ & Charges are based on the number of drums installed in the unit \\
\hline Ranipet & Charges are based on the Volume of Effluent Discharged \\
\hline & UTTAR PRADESH \\
\hline Banthar and Unnao & Charges are based on the Volume of Effluent Discharged \\
\hline Jajamau & Charges are based on the number of drums installed in the unit \\
\hline Kolkata & WEST BENGAL \\
\hline Jalandhar & Charges are based on the licensed processing capacity of the tanneries. \\
\hline Variation & PUNJAB \\
\hline
\end{tabular}

\section{Variation in CETP charges}

There is wide variance amongst clusters regarding the basis for charging CETP membership fee, there is a need to harmonize amongst them for the following reasons:

- Licensed capacity may be much larger than the current processing capacity as units may be underutilizing their capacity (as in Calcutta Leather Complex) so do not give exact estimation of Pollution Load.

- Numbers of drums installed may not give correct effluent load due to under functioning (drums installed but not utilized) or mal-functioning (effluent may be leaked off from damaged drums).

- Volume of Effluent Discharged though gives a clearer picture of effluent load, but however it does not clearly qualitatively estimates effluent for quality treatment. If effluent somehow gets diluted, it gives 
Tannery Clusters in India and waste management practices in tannery intensive states - inventory...

quantitatively greater effluent load. Lesser effluent volume may contain more pollutants in concentrated dilutions. So the methodology is biased.

Only logically correct method for unbiased and proportionate financial burden is the charges based on TDS load of the effluent as it is the most important pollution parameter in case of tanneries. More polluter pays more.

\section{Comparison of Chromium Management Practices}

As per Charter on Corporate Responsibility for Environmental Protection (CREP, 2003) for Leather Industry, implementation of individual or Common Chrome Recovery Systems (CCRS)

In Jalandhar Cluster (Punjab) though there is no common chrome recovery system, several unit have installed individual chrome recovery units. During survey it has been reported that individual Chrome recovery units are economical to the tanners as the payback period is only 1.5 to 2 years and suffices $35-40 \%$ of their chrome requirement.

Table: Comparison of chrome management in tannery intensive states

\begin{tabular}{|l|l|l|}
\hline \multirow{4}{*}{$\begin{array}{l}\text { Chrome } \\
\text { Recovery }\end{array}$} & T.N & $\begin{array}{l}\text { All are connected to Common Chrome Recovery Unit (CCRU). } \\
\text { There is no individual Chrome Recovery Units. }\end{array}$ \\
\cline { 2 - 3 } $\begin{array}{l}\text { Units } \\
\text { (CCRU) }\end{array}$ & U.P. & Units have either individual CRU or are members of CCRU in Kanpur \\
\cline { 2 - 3 } & W. Bengal & All the units are connected to CCRU in Kolkata leather complex. \\
\cline { 2 - 3 } & Punjab & $\begin{array}{l}\text { All units have individual Chrome Recover Units in Jalandhar cluster. } \\
\text { No Common Chrome Recovery Unit is present. }\end{array}$ \\
\hline
\end{tabular}

\section{Comparison of disposal of treated wastewater}

Tannery operations are water intensive hence water conservation is important particular in regions having acute water scarcity.

The Tamil Nadu Pollution Control Board has directed tannery CETPs to reuse treated waste water by installing MBR \& RO. However study shows that presently most of the treated waste water is being disposed off as per information compiled in Table below.

Table: Disposal of treated effluent in tannery intensive states

\begin{tabular}{|c|c|c|c|}
\hline \multicolumn{2}{|l|}{ TAMIL NADU } & \multicolumn{2}{|l|}{ WEST BENGAL } \\
\hline CETP & Disposal of treated waste water & CETP & Disposal of treatedwaste water \\
\hline Dindigul & $\begin{array}{l}\text { On land (HRTS system) \& } \\
\text { Sengankulam tank of CETP }\end{array}$ & \multirow{2}{*}{$\begin{array}{l}\text { Calcutta Leather } \\
\text { Complex }\end{array}$} & \multirow{2}{*}{$\begin{array}{l}\text { Disposed to Bay of Bengal through storm water } \\
\text { drain joining Vidyadhari River }\end{array}$} \\
\hline Pallavaram & Adyar River & & \\
\hline Madhavaram & MulakkadaiNullah & \multicolumn{2}{|c|}{ UTTAR PRADESH } \\
\hline Ranipet & Palar River through nallah & \multirow{2}{*}{ CETP } & \multirow{2}{*}{ Disposal of treatedwaste water } \\
\hline SIDCO-Phase I & On land (Irrigation) \&Ponnai Lake & & \\
\hline SIDCO-Phase II & Information not available & Banthar & $\begin{array}{l}\text { Treated waste water is conveyed to river Ganges } \\
\text { through } 10 \mathrm{kms} \text { long canal. }\end{array}$ \\
\hline Melvisharam & On land (Green belt) \&Palar River & Jajamau & $\begin{array}{l}\text { Waste water from tanneries is treated along with } \\
\text { sewage by UP Jal Nigam }\end{array}$ \\
\hline Pernambut & On land (HRTS system) \&Nullah & Unnao & $\begin{array}{l}\text { Treated waste water is conveyed to river Ganges } \\
\text { through municipal drain }\end{array}$ \\
\hline \multirow{4}{*}{ Vaniyambadi } & \multirow{4}{*}{ Palar River } & \multicolumn{2}{|l|}{ PUNJAB } \\
\hline & & CETP & Disposal of treatedwaste water \\
\hline & & Jalandhar & $\begin{array}{l}\text { Treated Waste water is released into river Sutlej } \\
\text { through Kalasingha drain. }\end{array}$ \\
\hline & & Phillaur & STP-Phillore \\
\hline
\end{tabular}

\section{Comparison of Solid Waste Management Practices}

Different solid wastes generated from tanneries are mostly used up except for the Sludge which is a major solid waste going for incineration.

Table: Solid waste management practices in tannery intensive states

\begin{tabular}{|c|c|c|c|c|}
\hline Solid Wastes & Tamil Nadu & Uttar Pradesh & West Bengal & Punjab \\
\hline Trimmings & $\begin{array}{l}\text { Major percentage taken away by } \\
\text { the raw hide suppliers } \\
\text { Sold to Glue manufacturers }\end{array}$ & & \multirow{4}{*}{ Same as Tamil Nadu } & \\
\hline Salt & $\begin{array}{l}\text { Partly reused for curing } \\
\text { Rest Sold to raw hide merchants }\end{array}$ & & & \\
\hline Hair & Disposed off as solid waste & & & \\
\hline $\begin{array}{l}\text { Fleshings \& Pelt } \\
\text { Trimmings }\end{array}$ & $\begin{array}{l}\text { Sold to glue manufacturer } \\
\text { sold to chicken feed } \\
\text { manufacturer }\end{array}$ & & & \\
\hline Lime Sludge & $\begin{array}{l}\text { Sold on truck load basis for } \\
\text { construction activities } \\
\text { Used for filling up low lying } \\
\text { areas }\end{array}$ & $\begin{array}{c}\text { Same as Tamil Nadu } \\
+ \\
\text { Used by Labors for } \\
\text { construction of huts }\end{array}$ & $\begin{array}{l}\text { Sold on truck load } \\
\text { basis for construction } \\
\text { activities }\end{array}$ & Same as Uttar Pradesh \\
\hline 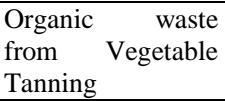 & $\begin{array}{l}\text { Used in boilers after drying } \\
\text { Sold to be used as fuel in brick } \\
\text { kilns }\end{array}$ & \multicolumn{3}{|c|}{ Same as Tamil Nadu } \\
\hline
\end{tabular}


Tannery Clusters in India and waste management practices in tannery intensive states - inventory...

\begin{tabular}{|c|c|c|c|c|}
\hline $\begin{array}{l}\text { Vegetable Tanned } \\
\text { Trimmings }\end{array}$ & \begin{tabular}{l}
\multicolumn{3}{l}{ Used for making leather boards } \\
Larger cuttings used for \\
Footwear manufacturing \& \\
repair
\end{tabular} & & & \\
\hline Chrome Shavings & $\begin{array}{l}\text { Used for making leather boards } \\
\text { Biomethanation of Chrome free } \\
\text { shavings }\end{array}$ & $\begin{array}{l}\text { Used for making leather } \\
\text { boards } \\
\text { Sold as fertilizer }\end{array}$ & \multirow{2}{*}{$\begin{array}{l}\text { Same as Uttar } \\
\text { Pradesh }\end{array}$} & Same as Uttar Pradesh \\
\hline $\begin{array}{l}\text { Chrome } \\
\text { Trimmings }\end{array}$ & Used for making Leather Boards & $\begin{array}{l}\text { Used for making } \text { Leather } \\
\text { Goods } \\
\text { Sold to Fertilizer } \\
\text { manufacturers }\end{array}$ & & $\begin{array}{l}\text { Used for making } \\
\text { leather boards }\end{array}$ \\
\hline Buffing dust & Disposed off as MSW & $\begin{array}{l}\text { Same as Tamil Nadu } \\
+ \\
\text { As Fuel for Boilers }\end{array}$ & $\begin{array}{l}\text { Used for filling low } \\
\text { lying areas } \\
\text { Partly used as fuel in } \\
\text { boilers in few } \\
\text { tanneries }\end{array}$ & As Fuel for Boilers \\
\hline $\begin{array}{l}\text { Pre-Treatment } \\
\text { Sludge }\end{array}$ & Disposed off in SLF & $\begin{array}{lcr}\begin{array}{l}\text { Partly } \\
\text { premises }\end{array} & \text { stored } & \text { within } \\
\begin{array}{l}\text { Dumped } \\
\text { cluster }\end{array} & \text { near } & \text { tannery } \\
\end{array}$ & $\begin{array}{l}\text { Stored within } \\
\text { premises and sent off } \\
\text { to SFL }\end{array}$ & Same as Uttar Pradesh \\
\hline
\end{tabular}

From the table below it is observed that most of the solid waste management practices are almost uniform across the clusters in the tannery intensive states.

\section{Conclusion and Future Prospects}

From the study it found that most of the tannery activities are concentrated in clusters. Cauterization provides a very beneficial tool for overall growth of the sector in a sustainable and self driving mechanism. Tanneries show a prominent shift towards the adoption of cleaner practices in recent decades with highest number of dedicated CETPs. $42 \%$ of clusters studied are connected to dedicated CETPs. There is data lacunae on the clusters in other states and further study need to be taken up.

\section{Acknowledgements}

The author is duly thankful to Central Pollution Control Board for funding the study and duly acknowledge the support of Sh. Nazimuddin, Sc-D, CPCB; Sh. G.S. Gill, Senior Environmental Engineer Punjab Pollution Control Board, Sh. Ajay Sharma, director PETS, Punjab, for field study in Punjab and Ex Member Secretary Sh. J.S Kamyotra, CPCB.

\section{References}

[1]. SME CLUSTERS IN INDIA Identifying Areas of Intervention for Inclusive Growth, sponsored by Planning Commission Government of India, by Prof. S.R. Hashim, Prof. M.R. Murthy, Dr. SatyakiRoy, ISID, Institute for Studies in Industrial Development, April 2010

[2]. Performance Status of Common Effluent Treatment Plants in India, Central Pollution Control Board, October 2005.

[3]. Central Pollution Control Board. Report on Potential for Adoption of Clean Technologies in SMEs AnIntroduction.IMPACTS/16/2011-12;2012.

[4]. Solid waste management in Leather Industries, S.V.Srinivasan, et.al; Department of Environmental Technology, Central Leather Research Institute.

[5]. The Indo-Italian Chamber of Commerce and Industry, IICCI - Short Market Overviews on the Indian Leather Industry, June 2008.

[6]. Indian Leather Sector Network Report:Sector Overview and SWOT Analysis, Sustainable Industrial Networks and Its applications on Micro. Regional Environmental Planning (SINET) 